\title{
NORTHANGER ABBEY AN INTRODUCTION
}

Sylvia Townsend Warner

(from Northanger Abbey by Jane Austen, Limited Editions Club, Garamond Press, 1971)

She grew on the sunny side of the wall-as it might be, one of those solid cob walls, white-washed and roofed with thatch, such as still enclose Hampshire kitchen-gardens. On such walls, in her day, Moor Park apricots, Bon Chretien and Jargonelle pears, Blue Perdrigon plums were trained and tended and brought forth their fruit in due season. The Rector of Steventon's daughter, growing on the sunny side of the rectory wall, produced in her early twenties Pride and Prejudice, Sense and Sensibility, and Northanger Abbey.

Steventon was a family living-the gift in 1764 of a kind cousin to the Reverend George Austen. He married, and begot five sons and two daughters. Not one of these died untimely, or took to evil courses, or suffered religious doubts: the pyrexia of Evangelical fervour had not yet penetrated the Church of England. It was a happy, healthy, loving family, at ease with the world yet not expecting too much of it, ready to be entertained by it but for the most part relying for entertainment on their own resources.

Mr Austen's contribution was to read aloud in the evenings. Though those who read aloud to a young family tend to choose books which they suspect their children would not read with much attention if left to choose for themselves, from time to time a personal preference will assert itself and an old favourite be taken from the bookcase. 
No doubt in these departures from histories, travels, essays from The Rambler, Mr Austen used some parental license as to what he should omit; but I am sure that Fielding was one of the authors he read aloud, and Smollett another. His younger daughter, hemming a handkerchief or stitching wristbands for a brother's shirt, had ears to hear.

For example:

It may now be proper to return to the Hero of this Novel of whom I beleive I have scarcely ever had occasion to speak: which may perhaps be partly oweing to his unfortunate propensity to liquor, which so completely deprived him of the use of those faculties Nature had endowed him with that he never did anything worth mentioning.

\section{And again:}

Lovely and too charming Fair one, notwithstanding your forbidding Squint, your greazy tresses and your swelling Back, which are more frightful than imagination can paint or pen describe, I cannot refrain from expressing my raptures, at the engaging qualities of your Mind, which so amply atone for the Horror, with which your first appearance must ever inspire the unwary visitor. Your sentiments so nobly expressed on the different excellencies of Indian and English Muslins, and the judicious preference you give the former...

The demure brutality of these passages from Volume the First of Jane Austen's Juvenilia shows what models she had her eye on.

There is also Mrs Austen to be taken into account. She enjoyed reading novels and was a subscriber to a Lending Library:

Her melancholy was assisted by the hollow sighings of the wind along the corridor and round the castle. The cheerful blaze of the wood had long been extinguished, and she sat with her eyes fixed on the dying embers, till a loud gust, that swept through the corridor, and shook the doors and casements, alarmed her, for its violence had moved the chair she had placed as fastening, and the door leading to the private staircase stood half open. 
The Mysteries of Udolpho appeared in 1794. It was not the first of its kind (The Castle of Otranto had thrown down its Gothic gauntlet thirty years earlier), nor was it Mrs Radcliffe's first novel in that genre; but it was the most compelling. The wind had never sighed more hollowly along gloomier corridors, footsteps had never sounded more alarmingly from battlements, mystery had never been concealed behind a more threatening assemblage of rusty bolts, decaying tapestries, secret stairways, vast echoing halls lit by a single taper, unvisited chambers with dreadful associations, midnight hours. One could say of it that it numbered only midnight hours. It numbered a vast quantity of breathless readers. And three years later, a young untrembling hand dipped a pen in an inkpot and began to make game of it. 'No one who had ever seen Catherine Morland in her infancy would have supposed her born to be an heroine.'

Of Jane Austen's novels, Northanger Abbey is the only one in which she shows herself concerned with literature. In the others, she minds her own business and is concerned with writing. The exclamation, "Nay, mamma, if he is not to be animated by Cowper! ... ," ' having served to throw light on Marianne Dashwood and the insensibly sensible Edward Ferrars, Cowper can be dismissed. But in Northanger Abbey she interrupts the narrative with critical opinions. Catherine Morland is not only a girl who makes a fool of herself because of her enthusiasm for The Mysteries of Udolpho. Her foolishness involves the foolishness of Mrs Radcliffe, and that of her imitators and that of her betters. For a moment, one glimpses the airy javelin from Steventon Rectory quivering on Goethe's buckskin breeches. Coming after the totally undogmatic narrative tone of Pride and Prejudice and Sense and Sensibility, these interpolations, these addressings of the reader, sound oddly pedantic. It is the pedantry of youth, however. It was as a young iconoclast, a representative of a nouvelle vague, that she assumed the mannerisms of Fielding in order to deride the unreality of the Romantics. But her finest strokes of critical demolition arise from the narrative itself. It is Mrs Allen, that pedestrian 
dullard, who breaches the massy walls of the Castle of Northanger.

Wherever they went, some pattened girl stopped to curtsey, or some footman in dishabille sneaked off. Yet this was an Abbey! How inexpressibly different in these domestic arrangements from such as she had read about; from abbeys and castles, in which, though certainly larger than Northanger, all the dirty work of the house was to be done by two pairs of female hands at the utmost. How they could get through it all had often amazed Mrs Allen; and, when Catherine saw what was necessary here, she began to be amazed herself

Authors are at the mercy of their successes; if it had not been for the swooning piety of Mrs Radcliffe's public, Jane Austen might not have felt the same youthful severity toward Mrs Radcliffe. Whatever the demerits of Udolpho, it was a novel; and in the matter of novel-reading Jane Austen remained her mother's daughter. In the longest of the critical discursions in Northanger Abbey she makes this plain:

If a rainy morning deprived them of other enjoyments, they were still resolute in meeting in defiance of wet and dirt, and shut themselves up to read novels together. Yes, novels. ... Let us leave it to the Reviewers to abuse such effusions of fancy at their leisure, and over every new novel to talk in threadbare strains of the trash with which the press now groans. Let us not desert one another; we are an injured body. Although our productions have afforded more extensive and unaffected pleasure than those of any other literary corporation in the world, no species of composition has been so decried. From pride, ignorance, or fashion, our foes are almost as many as our readers; and while the abilities of the nine-hundredth abridger of the History of England, or of the man who collects and publishes in a volume some dozen lines of Milton, Pope and Prior, with a paper from the Spectator, and a chapter from Sterne, are eulogized by a thousand pens, there seems almost a general wish of decrying the capacity and undervaluing the labour of the novelist, and of slighting the performances which have only genius, wit, and taste to recommend them. 
Of the two young ladies who shut themselves up to read novels together, Catherine Morland was one, and Udolpho her reading, with The Italian to follow it; and after them the other young lady promises her (she has the names in her pocket-book):

'Castle of Wolfenbach, Clermont, Mysterious Warnings, Necromancer of the Black Forest, Midnight Bell, Orphan of the Rhine, and Horrid Mysteries. Those will last us some time.' horrid?'

'Yes, pretty well; but are they all horrid, are you sure they are all

The opening of Northanger Abbey appears to comply with the requirements of such fiction. Catherine, young, unsophisticated, brought up in the country, is taken on a visit to Bath by the Allens, a rich childless couple. She rises another step in the world when she is introduced to 'a very gentleman-like young man,' called Henry Tilney. He in turn introduces her to his sister. They take her for walks, educate her in the Picturesque, have also read Udolpho. She falls in love, but without expectations, and without the conviction she would have felt if Henry Tilney had been a dispossessed heir instead of a younger son with a family living. To her amazement, she finds herself vehemently approved of by their alarming father, and invited to visit Northanger Abbey. An Abbey! actually an Abbey, with 'its long, damp passages, its narrow cells and ruined chapel,' and a reasonable hope of 'some awful memorials of an injured and ill-fated nun.' Her anticipations are slightly dashed by the Abbey being comfortable and commodious, but General Tilney's insistence that she should be pleased with it, his deference to her taste, his massive flatteries, reconcile her to well-lit rooms and carpeted floors. Besides, there are a number of corridors and unexplored rooms and these may reveal something very mysterious and very horrid. But the visit comes to a sudden end. Without a word of explanation, she is packed off to make her way home in a hired post-chaise.

As a heroine, she would expect some such startling misfortune. Torn from Henry Tilney, she would be prepared to 
spend the remainder of her shortened days in melancholy seclusion, walking by moonlight under willows and conifers-for as this is England, she cannot hope for cypresses, and as the daughter of a Church of England parson she can't retire to a convent. But this startling misfortune is no longer appropriate. Foiled at every turn in her quest for the dire secret of Northanger Abbey-perhaps it reposed in the contents of the massive chest, or in the paper that might constitute the 'awful memorials of an injured and ill-fated nun,' and not to mention a compelling suspicion that her host had either made away with his wife or was keeping her in a dungeon on bread and water-Catherine had abandoned all intentions of being a heroine and was thinking about being Mrs Henry Tilney. And with some warrant, in view of the appeal which began with 'Dear Miss Morland, consider the dreadful nature of the suspicions you have entertained' and concluded with 'Dearest Miss Morland, what ideas have you been admitting?'

For a young lady, no longer a heroine, to be packed off in a post-chaise at that point of the story was both mysterious and horrid; but it wasn't in keeping with Mrs Radcliffe.

In fact, Mrs Radcliffe was largely responsible. Jane Austen had taken a leaf out of her book. 'Mrs Radcliffe's method'-I quote from The Oxford Companion to English Literature-'was to arouse terror and curiosity by events apparently supernatural, but afterwards explained by natural means.' The natural means chosen by Jane Austen were the ordinary human failings of cupidity, credulity, boasting, and bad temper.

We have all heard (rather too often) of 'the little bit (two inches wide) of Ivory on which I work with so fine a Brush, as produces little effect after much labour.' Her own words. But she wrote them in 1816, and by that time she may have forgotten how effectively she dealt with the Thorpes when she had newly ripened her fine, brisk, tart flavour on the 
Rectory wall at Steventon. The Jane Austen who wrote Northanger Abbey was not far removed in years from the Jane Austen of the Juvenilia; but in the interval she had mastered the inestimable trick of appearing to write without animus. 'Give them enough rope,' she seems to say, 'and they will hang themselves.' Duly, they hang themselves. It is impossible to imagine a deathbed conversion for Mrs Norris, a change of heart for Lucy Steele. The Thorpes will forever be objects of Jane Austen's dislike, and preserved in that implacability they are the most lifelike characters in the book. One sees Isabella writhing her shoulders as she pursues her prey through the crowded Pump-room, one hears John's bragging gabble and loud guffaws, one pities his horse; if his mother were not so flaccidly maternal, one would pity his mother. They are odious, they are paltry, they are beneath derision; she employs none of that affable mockery with which she assailed the romantic conventions. Her dislike is searching, scornful, and serious.

To some degree, it is also social. Jane Austen's classsensitivity is typically British in the way it distinguishes between gentry and gentility. Seen in one light, the Thorpes are laudably engaged in trying to better themselves, to look out for what may be to their advantage, to get on in the world. Jane Austen sees them as upstarts. The crowning stroke of her dislike is that she disallows their pretensions. Despite their instrumentality in the story, where their ordinary human failings of cupidity, mendacity, etc., subserve Catherine's ignominious dismissal, they remain jostling and insignificant.

For if Thorpe had not believed that Catherine was an heiress and that he was sure to get her-if General Tilney had not believed Thorpe's brag and decided to filch the heiress to fatten Northanger, and had not subsequently believed Thorpe's sour-grapes declaration that she was pennilessthere would have been no dismissal. The narrative arches from the credulity of those who crave for castles to the credulity of those who scheme for money. The only disinterested person (for Henry Tilney is not quite above 
reproach: before he sighed as a lover he was ready to obey as a son) is Catherine. She alone is not a time-server. It was a dream she served.

Maiden Newton

Dorchester, Dorset

September, 1970 